\title{
Diaspores and phyto-remains accidentally transported to the Antarctic Station during three expeditions
}

\author{
Maria Lityńska-Zając $\cdot$ Katarzyna Chwedorzewska $\cdot$ \\ Maria Olech • Małgorzata Korczak-Abshire • \\ Anna Augustyniuk-Kram
}

Received: 13 May 2012/ Accepted: 17 September 2012/Published online: 27 September 2012

(C) The Author(s) 2012. This article is published with open access at Springerlink.com

\begin{abstract}
The aim of the project was to assess the size and species range of alien plant diaspores and phyto-remains transported into the Polish Antarctic Station during three Antarctic expeditions. Our study clearly demonstrates that many diaspores can be quite easily unintentionally transported in good conditions to the Antarctic. In the analyzed material there were present diaspores of invasive species. All identified species belong to 20 families. The most abundant were Asteraceae and Poaceae species. The most interesting finding was the presence of caryopses of Poа апnиа, the first alien angiosperm species which already established a stable breeding population in the Antarctic. Base on our results, we can predict that risk of establishment of anther alien plant species in the vicinity of "Arctowski" Station is very high.
\end{abstract}

Keywords Alien species · Human impact · Antarctica

\section{Introduction}

Antarctic terrestrial ecosystems are noted for their relative simplicity and are characterized by low diversity, as well as an extremely low contribution of some families, or even lack of

\footnotetext{
M. Lityńska-Zając

Institute of Archaeology and Ethnology PAS, Sławkowska 17, 31-016 Cracow, Poland e-mail: marialitynska@gazeta.pl
}

K. Chwedorzewska $(\bowtie) \cdot$ M. Olech $\cdot$ M. Korczak-Abshire

Department of Antarctic Biology, Institute of Biochemistry and Biophysics PAS, Pawińskiego 5a, 02-106 Warsaw, Poland

e-mail: kchwedorzewska@go2.pl

M. Olech

Institute of Botany, Jagiellonian University, Kopernika 27, 31-501 Cracow, Poland

A. Augustyniuk-Kram

Centre for Ecological Research, Polish Academy of Sciences, M. Konopnickiej 1,

Dziekanów Leśny, 05-092 Łomianki, Poland 
them (Convey 2005). Antarctic tundra are predominantly cryptogamic (lichens, mosses, algae and liverworts) (Bednarek-Ochyra et al. 2000; Chwedorzewska et al. 2004, Ochyra et al. 2008; Olech 2004) and characterized by the poverty of flowering plants. Only two angiosperms thrive in harsh conditions of the maritime Antarctica climate: Deschampsia antarctica and Colobanthus quitensis. Low diversity, relatively simple community structure, and the general life history features of the native biota make Antarctic ecosystems very vulnerable to the impacts of introduced species (Convey 1996; Frenot et al. 2005; Terauds et al. 2012), particularly those that have sufficient genetic or phenotypic plasticity to enable them to adapt to the polar environment (Hughes et al. 2010a).

The rapid climate change in the western maritime Antarctic region already has significant and measurable impacts on almost all ecosystems. The consequences of these changes are generally expected to include: increased terrestrial diversity, biomass and trophic complexity, all of which contribute to more development of more complex ecosystem structure (Convey 2006). Combined with ameliorating growth conditions, the likelihood of colonisation by new populations of native and alien species is projected to increase in a warmer climate (Hughes et al. 2006; Korczak-Abshire et al. 2011). The two vascular plants native to the maritime Antarctic have provided the most studied examples of a measured biological response to the recent environmental warming in this region (McGraw and Day 1997; Gerighausen et al. 2003). In three decades some local populations have increased by as much as two orders of magnitude (Convey 1996, McGraw and Day 1997). More than a hundred non-indigenous plant species are already documented as having become established in sub-Antarctica islands (Frenot et al. 2005). There is currently only one analogous example in the Antarctic maritime zone: Poa annua, which is already established on King George Island (South Shetland Islands, Western Antarctic) (Olech 1996, 1998; Chwedorzewska 2008; Olech and Chwedorzewska 2011).

The Antarctic is isolated from the rest of the world by a natural barrier like oceanic and atmospheric circulation patterns around the continent that strongly limits the dispersal of organisms into and out of this region. But the extent of human activity is breaking it down (Chwedorzewska and Korczak 2010; Lee and Chown 2009a). With a considerable expansion of scientific expeditions and supporting logistics, as well as a remarkable rise of tourism in XXI century, the risk of alien species invasion increased. There is a significant number of tourists visiting the Antarctic, particularly the Scotia Arc region, but a scientific expedition bringing huge amount of cargo and equipment creates considerably higher impacts on the terrestrial ecosystems (Hughes et al. 2011; Chwedorzewska and Korczak 2010). Most stations and bases have a high probability of causing adverse influences on the terrestrial ecosystems due to their localization in coastal ice-free areas, which are also favourable to biological communities (Rakusa-Suszczewski and Krzyszowska 1991; Terauds et al. 2012).

With the current trend in regional warming in the maritime Antarctic (King et al. 2003) and a growing number of visitors, there is an increasing probability that plants, previously unable to survive due to adverse climatic conditions, will be able to become established (Chown et al. 2012b). Direct observation of diaspore migrations is very hard and possible after their establishment in the new environment. The only way to monitor the pressure of alien organisms is a detailed examination of cargo, personal luggage, clothes and equipment of people visiting Antarctic stations.

The main goal of this project was to assess the size and species range of alien diaspores and phyto-remains transported into the Polish Antarctic Station "H. Arctowski" during three Antarctic expeditions. 


\section{Materials and Methods}

In three austral summer seasons: 2007/2008, 2008/2009, 2009/2010, clothes and equipment of the Antarctic Expedition participants coming to the Polish Antarctic Station "H. Arctowski" (King George Island, South Shetland Islands, $62^{\circ} 09^{\prime} \mathrm{S}, 58^{\circ} 28^{\prime} \mathrm{W}$ ) were examined for the presence of alien diaspores and phyto-remains.

All personal field clothing, gear and equipment of expeditioners (scientists and support personnel) during three seasons were vacuumed-each sample to a separate dust bag. A new nylon stocking filter was put on the vacuum cleaner pipe to collect the bigger contaminations. Seeds and phyto-remaind stick to Velcro ${ }^{\circledR}$ fasteners on clothing, boots and outdoor items were removed with tweezers. Each collected sample was tagged, placed in a separate zip lock bag and preserved for transportation to Poland for future analysis.

All samples were analyzed in the laboratory of the Institute of Archaeology and Ethnology Polish Academy of Science in Cracow. After measuring the volume $0.5-5 \mathrm{~cm}^{3}$, material was sorted under macroscopic binoculars. From each sample all plant material: seeds, caryopses, fruits and vegetative fragments like pieces of wood, leaves or stems, were selected.

Plant material was found in 78 samples. Identification of seeds and fruits was based on a comparison with samples in a reference collection of the Institute of Archaeology and Ethnology PAS laboratory, as well as the herbarium of the Department of Paleobotany, W. Szafer Institute of Botany PAS and specialist literature (Klan 1947; Kowal 1953; Sajak 1958; Wojciechowska 1966, 1972; Dörter 1968; Kowal and Rudnicka-Sternowa 1969; Swarbrick and Raymond, 1970a, 1970b; Rudnicka-Sternowa 1972; Conolly 1976; Rymkiewicz 1979; Cappers et al. 2006, 2009).

Vegetative parts, including pieces of wood, were indentified according to their anatomic structures (e.g., Schweingruber 1990). Each fragment of wood was broken along three anatomical sections and examined microscopically, using a metallographic microscope. Identifications were made by comparison with anatomical atlases and specimens in a reference collection. Detailed information was obtained by studying one hundred slides with a scanning electron microscope.

Cumulative degree days for low-temperature vascular plant species (assuming that species can germinate, survive and grow above $-5^{\circ} \mathrm{C}$; Bannister 2007) were calculated based on meteorological data for "Arctowski" oasis from our database. The risk index for "Arctowski" oasis were calculated according Chown et al. (2012a).

\section{Results}

During three seasons seventy-eight samples were collected. The distribution of plant material among the samples was irregular. In one sample there were many plant species recorded, whereas there were almost no plant remains in others.

In general, plant material was very well preserved and contained intact diaspores, sometimes with traces of mechanic damage on the external surface. In total, 214 plant fragments were found (Table 1), among them there were 114 diaspores. In eleven samples (14\%) there were no diaspores. In average there were 1.7 diaspores per expeditioner (per person carrying seeds). There were 49 diaspores of species occur in cold region like Arctic and sub-Antarctic.

The majority of plant material was assigned to forty-six species. Based on wood analysis only one tree species was identified as pine Pinus sylvestris (Table 2). 
Table 1 Type and number of plant remains preserved in 78 analyzed samples

\begin{tabular}{lc}
\hline Type of specimens & $\begin{array}{c}\text { Numbers of } \\
\text { specimens }\end{array}$ \\
\hline Wood & 5 \\
Spikelet & 34 \\
Leaves & 26 \\
Stem & 5 \\
Fruit scale & 3 \\
Seed & 22 \\
Fruit & 71 \\
Needle & 26 \\
Cone & 1 \\
Caryopsis & 21 \\
Total & 214 \\
\hline
\end{tabular}

Incompletely preserved specimens were determined to a genus, some only to the family level (Tables 3, 4).

The analyzed diaspores belong mainly to herbaceous plants, only one species of tree (Betula pendula) was represented in the collected seed material. But in vegetative remains wood fragments of Pinus sylvestris, linden (genus Tilia) and birch (genus Betula) were identified. In the collected material there were also identified needles of Pinus sylvestris and some hard to determine fragments of needles belonging to a species from Coniferae family. We also found fragments of a larch cone Larix decidua.

Straw fragments belonging to Poaceae were present in numerous samples. Also a lot of unidentified fragments of leaf blades, characteristic to Dicotyledoneae were found in numerous samples. The whole material contained a lot of unidentified phyto-remains.

All identified species belong to twenty families, representing plants from Dicotyledoneae and Monocotyledoneae (Table 3). Asteraceae and Poaceae families were the most abundant in genera: 9 and 7, respectively. The same families were also the most abundant in species: Asteraceae-10 and Poaceae-6. The most diaspore and phyto-remain specimens belonged to Poaceae and Pinaceae families, but Pinaceae were represented mostly by vegetative fragments, like needles. In the collected material diaspores of Asteraceae family accounted significant participation. The most numerously represented species was Echinochloa crus-galli (caryopses and spikelet). The Polygonaceae was represented by two genera, including five species (ten diaspores).

The average cumulative annual degree days during three summer season was about 1,450. The relative risk of alien vascular plants establishing for "Arctowski" oasis was high and after normalization (to provide a probability of risk from 0 to 1 ) reach about 0.81 .

\section{Discussion}

Phyto-remains and diaspores were found mainly on clothing, gear and equipment of expeditioners that had spent the previous six months in Poland, thus the probability that the majority of the investigated plant material originated from this region was very high. In our study average number of seed per person carrying plant diaspors were lower than in Chown et al. 2012a, thus probably because about half of investigated people spend about forty 
Table 2 Species identified on the basis of well preserved plant material collected in the Antarctic

\begin{tabular}{|c|c|c|c|c|c|c|}
\hline $\begin{array}{l}\text { S. } \\
\text { no }\end{array}$ & Familly & Species & $\begin{array}{l}\text { Numbers of } \\
\text { specimens }\end{array}$ & $\begin{array}{l}\text { Type of } \\
\text { specimens }\end{array}$ & $\begin{array}{l}\text { Present in } \\
\text { Arctic }\end{array}$ & $\begin{array}{l}\text { Present } \\
\text { in sub- } \\
\text { Antarctic }\end{array}$ \\
\hline 1 & Asteraceae & Cirsium arvense & 2 & Fruit & $\begin{array}{l}\text { Indigenous EH/ } \\
\text { alien WH }\end{array}$ & Alien \\
\hline 2 & Asteraceae & Galinsoga parviflora & 2 & Fruit & - & - \\
\hline 3 & Asteraceae & $\begin{array}{l}\text { Hieracium cf. } \\
\text { glaucinum }\end{array}$ & 1 & Fruit & - & - \\
\hline 4 & Asteraceae & Lactuca serriola & 6 & Fruit & - & - \\
\hline 5 & Asteraceae & Leontodon autumnalis & 2 & Fruit & Indigenous & - \\
\hline 6 & Asteraceae & Leontodon hispidus & 1 & Fruit & - & - \\
\hline 7 & Asteraceae & $\begin{array}{l}\text { Leucanthemum } \\
\text { vulgare }\end{array}$ & 7 & Fruit & $\begin{array}{l}\text { Indigenous EH/ } \\
\text { alien WH }\end{array}$ & Alien \\
\hline 8 & Asteraceae & Picris hieracioides & 1 & Fruit & - & - \\
\hline 9 & Asteraceae & Sonchus arvensis & 1 & Fruit & $\begin{array}{l}\text { Indigenous EH/ } \\
\text { alien WH }\end{array}$ & - \\
\hline 10 & Apiaceae & $\begin{array}{l}\text { Chaerophyllum } \\
\text { hirsutum }\end{array}$ & 6 & Fruit & - & - \\
\hline 11 & Apiaceae & Pastinaca sativa & 1 & Fruit & - & - \\
\hline 12 & Betulaceae & Betula pendula & 3 & Husk & - & - \\
\hline 13 & Betulaceae & Betula pendula & 6 & Fruit & - & - \\
\hline 14 & Caryophyllaceae & Lychnis flos-cuculi & 1 & Seed & - & - \\
\hline 15 & Chenopodiaceae & Chenopodium album & 5 & Seed & $\begin{array}{l}\text { Indigenous EH/ } \\
\text { alien WH }\end{array}$ & - \\
\hline 16 & Cyperaceae & Carex disticha & 1 & Fruit & $\begin{array}{l}\text { Indigenous EH/ } \\
\text { alien WH }\end{array}$ & - \\
\hline 17 & Cyperaceae & Schoenus ferrugineus & 1 & Fruit & - & - \\
\hline 18 & Cyperaceae & $\begin{array}{l}\text { Schoenus cf. } \\
\text { nigricans }\end{array}$ & 1 & Fruit & - & - \\
\hline 19 & Fabaceae & Trifolium arvense & 2 & Seed & - & - \\
\hline 20 & Fabaceae & $\begin{array}{l}\text { Trifolium } \mathrm{cf} . \\
\text { campestre }\end{array}$ & 1 & Seed & - & - \\
\hline 21 & Lamiaceae & Nepeta cataria & 1 & Fruit & Alien & - \\
\hline 22 & Lamiaceae & Nepeta pannonica & 8 & Fruit & - & - \\
\hline 23 & Linaceae & Linum usistatissimum & 2 & Seed & - & - \\
\hline 24 & Papaveraceae & Papaver somniferum & 3 & Seed & - & - \\
\hline \multirow[t]{2}{*}{25} & Plantaginaceae & Plantago lanceolata & 3 & Seed & $\begin{array}{l}\text { Indigenous EH/ } \\
\text { alien WH }\end{array}$ & Alien \\
\hline & Plantaginaceae & Plantago major & 1 & Seed & $\begin{array}{l}\text { Indigenous EH/ } \\
\text { alien WH }\end{array}$ & - \\
\hline 25 & Pinaceae & Larix deciduas & 1 & Cone & - & - \\
\hline 26 & Pinaceae & Pinus sylvestris & 2 & Wood & - & - \\
\hline 27 & Pinaceae & Pinus sylvestris & 25 & Needle & - & - \\
\hline 30 & Poaceae & $\begin{array}{c}\text { Anthoxanthum } \\
\text { odoratum }\end{array}$ & 1 & Spikelet & $\begin{array}{l}\text { Indigenous EH/ } \\
\text { alien WH }\end{array}$ & - \\
\hline 31 & Poaceae & Avena sativa & 1 & Spikelet & - & - \\
\hline 32 & Poaceae & Avena sativa & 1 & Caryopses & - & - \\
\hline
\end{tabular}


Table 2 continued

\begin{tabular}{|c|c|c|c|c|c|c|}
\hline $\begin{array}{l}\text { S. } \\
\text { no }\end{array}$ & Familly & Species & $\begin{array}{l}\text { Numbers of } \\
\text { specimens }\end{array}$ & $\begin{array}{l}\text { Type of } \\
\text { specimens }\end{array}$ & $\begin{array}{l}\text { Present in } \\
\text { Arctic }\end{array}$ & $\begin{array}{l}\text { Present } \\
\text { in sub- } \\
\text { Antarctic }\end{array}$ \\
\hline 33 & Poaceae & Bromus secalinus & 1 & Spikelet & Alien & - \\
\hline 34 & Poaceae & Bromus secalinus & 1 & Caryopses & Alien & - \\
\hline 35 & Poaceae & $\begin{array}{l}\text { Echinochloa crus- } \\
\quad \text { galli }\end{array}$ & 10 & Spikelet & - & - \\
\hline 36 & Poaceae & $\begin{array}{l}\text { Echinochloa crus- } \\
\quad \text { galli }\end{array}$ & 2 & Caryopses & - & - \\
\hline 37 & Poaceae & Роа аппиа & 1 & Spikelet & $\begin{array}{l}\text { Indigenous EH/ } \\
\text { alien WH }\end{array}$ & Alien \\
\hline 38 & Poaceae & Роа аппиа & 5 & Caryopses & $\begin{array}{l}\text { Indigenous EH/ } \\
\text { alien WH }\end{array}$ & Alien \\
\hline 39 & Poaceae & Setaria pumila & 3 & Spikelet & - & - \\
\hline 40 & Poaceae & Setaria pumila & 1 & Caryopses & - & - \\
\hline 41 & Polygonaceae & Polygonum aviculare & 1 & Fruit & $\begin{array}{l}\text { Indigenous EH/ } \\
\text { alien WH }\end{array}$ & - \\
\hline 42 & Polygonaceae & $\begin{array}{l}\text { Polygonum } \\
\text { lapathifolium subsp. } \\
\text { lapathifolium }\end{array}$ & 1 & Fruit & Alien & - \\
\hline 43 & Polygonaceae & Polygonum persicaria & 3 & Fruit & $\begin{array}{l}\text { Indigenous EH/ } \\
\text { alien WH }\end{array}$ & - \\
\hline 44 & Polygonaceae & Rumex acetosa & 3 & Fruit & $\begin{array}{l}\text { Indigenous EH/ } \\
\text { alien WH }\end{array}$ & - \\
\hline 45 & Polygonaceae & Rumex acetosella & 2 & Fruit & $\begin{array}{l}\text { Indigenous EH/ } \\
\text { alien WH }\end{array}$ & Alien \\
\hline 46 & Ranunculaceae & Ranunculus acris & 1 & Fruit & $\begin{array}{l}\text { Indigenous EH/ } \\
\text { alien WH }\end{array}$ & - \\
\hline 47 & Ranunculaceae & Ranunculus repens & 1 & Fruit & $\begin{array}{l}\text { Indigenous EH/ } \\
\text { alien WH }\end{array}$ & Alien \\
\hline 48 & Rosaceae & Fragaria vesca & 1 & Fruit & Indigenous & - \\
\hline 49 & Rosaceae & Geum urbanum L. & 1 & Fruit & - & - \\
\hline 50 & Rosaceae & Potentilla norvegica & 1 & Fruit & $\begin{array}{l}\text { Indigenous EH/ } \\
\text { alien WH }\end{array}$ & - \\
\hline 51 & Rubiaceae & Galium aparine & 4 & Fruit & Indigenous & Alien \\
\hline 52 & Solanaceae & Solanum nigrum & 2 & Seed & - & - \\
\hline 53 & Urticaceae & Urtica dioica & 1 & Seed & Indigenous & - \\
\hline
\end{tabular}

EH Eastern Hemisphere

WH Western Hemisphere

days at the sea, travelling from Poland to the Station with limited contact with plant propagules.

There were identified some species common in agriculture areas, such as cereal weeds: Bromus secalinus and root crops weeds: Galinsoga parviflora, Setaria pumila and Echinochloa crus-galli, or species characteristic for ruderal communities: Chenopodium album. Species characteristic for natural communities, like forests and meadows: Leucanthemum vulgare and Lychnis flos-cuculi, were also present in the analyzed material. Three species of crop plants: linen Linum usitatissimum, poppy Papaver somniferum and oat Avena 
Table 3 The genus identified on the basis of poorly preserved plant material collected in the Antarctic

\begin{tabular}{llll}
\hline Genus & Family & $\begin{array}{l}\text { Numbers of } \\
\text { specimens }\end{array}$ & $\begin{array}{l}\text { Type of } \\
\text { specimens }\end{array}$ \\
\hline Betula & Betulaceae & 2 & Wood \\
Carex & Cyperaceae & 2 & Fruit \\
Crepis & Asteraceae & 1 & Fruit \\
Melica & Poaceae & 1 & Fruit \\
Melica & Poaceae & 1 & Spikelet \\
Tilia & Tiliaceae & 1 & Wood \\
\hline
\end{tabular}

\begin{tabular}{llc}
\hline Families or groups & Type & $\begin{array}{l}\text { Numbers of } \\
\text { specimens }\end{array}$ \\
\hline Cerealia & Caryopses & 8 \\
Coniferae & Needle & 1 \\
Dicotyledones & Leaf & 18 \\
Fabaceae & Seed & 1 \\
Poaceae & Spikelet & 16 \\
Poaceae & Leaf & 8 \\
Poaceae & Stem & 5 \\
Poaceae & Caryopses & 3 \\
\hline
\end{tabular}

Table 4 Identified families or groups of poorly preserved plant collected in the Antarctic sativa, commonly used for food products like pastry or muesli, were found. But among collected material were also present species with range covering polar regions of Northern Hemisphere like for example: Leontodon autumnalis, Carex disticha or Poa annua. Some of them are highly invasive e.g., P. апnиa or Cirsium arvense (www.cbd.int/invasive/data base.shtml) and already establish in sub-Antarctic. A lot of identified species are native to cold region of Eastern Hemisphere and alien to Western Hemisphere (Table 2).

The most interesting finding was the presence of caryopses and remains of spikelet of $P$. апnиa in the analysed material. There were several reports of alien plants occurring close to Antarctic stations (e.g., Smith 1996; Hughes et al. 2010a; Hughes and Convey 2010; Chwedorzewska 2009; Hughes and Convey 2010), but only P. annua has survived specific maritime Antarctic conditions for many years and established a stable breeding population (Olech and Chwedorzewska 2011). Poa апnиa is one of the most widely distributed plants in the world, native to Eurasia (Tutin 1952). It is a synanthropic and pioneer species (Huff 2003), adapted to a broad range of climate conditions (e.g., Frenot et al. 2001) and able to colonize such harsh environments as the maritime Antarctic. Initially P. апnиa was recorded in the Polish Antarctic Station H. Arctowski King George Island $\left(62^{\circ} 09^{\prime} \mathrm{S}\right.$ and $\left.58^{\circ} 28^{\prime} \mathrm{W}\right)$ in 1985 . Followed by a gradual increase of the $P$. annua population size, first the colonization of synantrophic places (Olech 1996, 1998), then of the forefield of retreat glacier areas (Olech and Chwedorzewska 2011) by this grass took place.

Finding caryopses in the analysed material seems to support the genetic analysis of $P$. аппиа population from "Arctowski". This investigation points out that the Antarctic population was probably founded by multiple introduction from different sources (Chwedorzewska 2008). This evidence supports the hypothesis of constant flow of fresh 
genetic material of this species to the vicinity of the station, which is reflected by an astonishingly high genetic variability in the introduced population (Chwedorzewska 2008; Chwedorzewska and Bednarek 2012). Роа апnиа's independent establishment were also

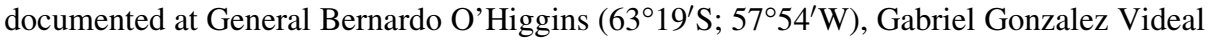
$\left(64^{\circ} 49^{\prime} \mathrm{S} ; 62^{\circ} 51^{\prime} \mathrm{W}\right)$ and Almirante Brown Stations $\left(64^{\circ} 52^{\prime} \mathrm{S} ; 62^{\circ} 54^{\prime} \mathrm{W}\right)$. Thus located along the Antarctic Peninsula and associated archipelagoes (Chown et al. 2012a, MolinaMontenegro et al. 2012). In the analyzed material there were also diaspores of other invasive species, for example: Cirsium arvense and Galinsoga parviflora (www.cbd. int/invasive/database.shtml).

The range of the diaspores introduced by expeditions is very wide. Most of them seem not to create a real threat for the Antarctic ecosystem, like for example schizocarps of Galium aparine adopted to zoochory or antropochory, or cultivated species like Linum usitatissimum and Papaver somniferum. Seeds of the two last-named species are commonly used for pastries, and could be transported with bread. These are expected to be unviable after baking. But some species numerously represented in the collected material diasporas, like these from Asteraceae family, which are adopted to anemochory, may disperse relatively easily by strong Antarctic winds. If they have the ecophysiological features required for survival in the polar environment, they could create a potential threat.

The way of reproduction is also very important in the potential invasiveness of species in the Antarctic. Species that reproduce vegetatively or are self-pollinated or anemophilous have a better chance to establish a breeding population than entomophilus species, due to the fact that in the whole Antarctic indigenous free-living entomofauna is extremely rare, with the lack of groups of pollinating insects. Only two native species of Diptera (Chironomidae) are found on the western shore of the Antarctic Peninsula and the associated archipelagos (Vernon et al. 1998) Parochlus steinenii and Belgica antarctica (Usher and Edwards 1985) and two non-native terrestrial invertebrates: Eretmoptera murphyi Schaeffer and Christensenidrilus blocki Dozsa-Farkas and Convey (Hughes and Worland 2010) found on Signy Station (South Orkney Islands). But according to our experience, through supply of the research stations a wide range of alien invertebrates can be accidentally transported in viable state and ultimately introduced to the Antarctic (Chwedorzewska in prep.). So, the two functional groups of alien organisms reached this region simultaneously: entomophilus plants and pollinator insects, which could potentially create a new synergy. On the local scale it already happens in the sub-Antarctic, where two representatives of a new ecological functional group-pollinating insects: Eristalis croceimaculata Jacobs (Diptera: Syrphidae) and Calliphora vicina Robineau-Desvoidy (Diptera: Calliphoridae) were established (Convey et al. 2010).

The range of the species found in our studies was similar to that found by Lee and Chown (2009b) in connection with materials required to construct Halley VI Antarctic Station (Dronning Maud Land) and by Chown et al. (2012a). A high proportion of species were from the taxa including globally invasive species, the most represented families were Poaceae and Asteraceae (Lee and Chown 2009b). However, alien plants are not as extensively established in the maritime Antarctic as they are on sub-Antarctic islands (Bergstrom and Smith 1990). In the sub-Antarctic Islands Frenot et al. (2005) already recorded 108 alien vascular plants and likewise the most abundant families were Poaceae (39), Asteraceae (20). They have not only survived but also spread and successfully competed with native species (Frenot et al. 1999, 2001; Gremmen and Smith 1999; Gremmen et al. 1998), thus they may serve as a potential source of exotic biota to the ameliorating maritime Antarctic. 
Our study clearly demonstrates that many diaspores can be quite easily unintentionally transported in good condition to the Antarctic (Hughes et al. 2010a, b). After crossing the dispersal barrier, the next question is whether these species would be able to cross the next philological barrier and survive in harsh conditions of the polar regions. According to Chown et al. (2012a) the region of the Antarctic Peninsula and Scotia Arc archipelagos are predicted to have the highest risk of alien plant establishment, due to such factors like annual cumulative degree days for plant (measure of environmental suitability), risk index (based on propagule pressure and origin, and climate suitability of the ice-free area). Our results are in agreement with Chown's et al. (2012a) estimates. Thus, spatial location (at the Antarctic Peninsula region) and quite intensive human pressure: both tourist and expeditioner (Chwedorzewska and Korczak 2010), favourable microclimate condition (Kejna 2008), big ice-free area (about $25 \mathrm{~km}^{2}$ ), newly exposed big glacial forelands, put "Arctowski" oasis in the highest risk group. Substantiation of this assessment is provided by rapid grow and spread of population of $P$. аnnua (Olech and Chwedorzewska 2011).

Thus, we can predict that in a very near future next flexible plant species characterized by a very wide ecological amplitude, high adaptation capabilities and diverse ways of reproduction may conquer changing environmental conditions and colonize the "Arctowski" oasis. Estimated risk of this incident is very high.

Acknowledgments This research project was supported by the Ministry of Scientific Research and Higher Education Grant IPY/27/2007. The authors would like to thank all persons involved in collecting materials during the XXX, XXXI and XXXII Polish Antarctic Expeditions. The authors would like to thank Prof. Ewa Zastawniak-Birkenmajer for the access to the collection of seeds and herbarium.

Open Access This article is distributed under the terms of the Creative Commons Attribution License which permits any use, distribution, and reproduction in any medium, provided the original author(s) and the source are credited.

\section{References}

Bannister P (2007) A touch of frost? Cold hardiness of plants in the southern hemisphere. N Z J Bot 45:1-33 Bednarek-Ochyra H, Ochyra R, Vana J, Lewis-Smith RI (2000) The liverwort flora of Antarctica. Polish Academy of Science, Cracow

Bergstrom DM, Smith VR (1990) Alien vascular flora of Marion and Prince Edward Islands: new species, present distribution and status. Antarct Sci 2:301-308

Cappers RTJ, Bekker RM, Jans JEA (2006) Digital seed atlas of the Netherlands. Groningen Archaeological Studies, Barkhuis

Cappers RTJ, Neef R, Bekker RM (2009) Digital atlas of economic plants. Part 1, 2a, 2b. Groningen Archaeological Studies, Barkhuis

Chown SL, Huiskes AHL, Gremmen NJM, Lee JE, Terauds A, Crosbie K, Frenote Y, Hughes KA, Imura S, Kiefer K, Lebouvierh M, Raymond B, Tsujimoto M, Warec C, Van de Vijverk B, Bergstrom DM (2012a) Continent-wide risk assessment for the establishment of nonindigenous species in Antarctica. Proc Natl Acad Sci USA 109:4938-4943

Chown SL, Lee JE, Hughes KA, Barnes J, Barrett PJ, Bergstrom DM, Convey P, Cowan DA, Crosbie K, Dyer G, Frenot Y, Grant SM, Herr D, Kennicutt II MC, Lamers M, Murray A, Possingham HP, Reid K, Riddle MJ, Ryan PG, Sanson L, Shaw JD, Sparrow MD, Summerhayes C, Terauds A, Wall DH (2012b) Challenges to the future conservation of the Antarctic. Science 337:158-159. www.sciencemag.org

Chwedorzewska KJ (2008) Poa апnиa L. in Antarctic: searching for the source of introduction. Polar Biol 31:263-268

Chwedorzewska KJ (2009) Terrestrial Antarctic ecosystems in the changing world: an overview. Pol Polar Res 30:263-276 
Chwedorzewska KJ, Bednarek PT (2012) Genetic and epigenetic variation in a cosmopolitan grass (Poa апnиa L.) from Antarctic and Polish populations. Pol Polar Res 33:63-80

Chwedorzewska KJ, Korczak M (2010) Human impact upon the environment in the vicinity of Arctowski Station, King George Island, Antarctica. Pol Polar Res 31:45-60

Chwedorzewska KJ, Bednarek PT, Puchalski J (2004) Molecular variation of Antarctic grass Deschampsia antarctica Desv. from King George Island (Antarctica). Acta Soc Bot Pol 73:23-29

Conolly A (1976) Use of the scanning electron microscope for the identification of seeds, with special references to Saxifraga and Papaver. Folia Quat 47:29-37

Convey P (1996) The influence of environmental characteristics on life history attributes of Antarctic terrestrial biota. Biol Rev 71:191-225

Convey P (2005) Antarctic terrestrial ecosystems: responses to environmental change. Polarforschung 75:101-111

Convey P (2006) Antarctic climate change and its influences on terrestrial ecosystems. In: Bergstrom DM, Convey P, Huiskes AHL (eds) Trends in Antarctic terrestrial and limnetic ecosystems: Antarctica as a global indicator. Springer, Dordrecht, pp 253-272

Convey P, Key RS, Key RJD (2010) The establishment of a new ecological guild of pollinating insects on sub-Antarctic South Georgia. Antarct Sci 22:508-512

Dörter K (1968) Das Bestimmen der Samen von Gräsern and Schmetlerlingsblutelern. Veb Deuscher Landwirtschaftsverlag, Berlin

Frenot Y, Aubry M, Misset MT, Gloaguen JC, Gourret JP, Lebouvier M (1999) Phenotypic plasticity and genetic diversity in Poa апnиа L. (Poaceae) at Crozet and Kerguelen Is. (sub-antarctic). Polar Biol 22:302-310

Frenot Y, Gloaguen JC, Masse L, Lebouvier M (2001) Human activities, ecosystem disturbance and plant invasions in sub-Antarctic Crozet, Kerguelen and Amsterdam Islands. Biol Conserv 101:33-50

Frenot Y, Chown SL, Whinam SL, Selkirk PM, Convey P, Skotnicki M, Bergstrom DM (2005) Biological invasions in the Antarctic: extent, impacts and implications. Biol Rev 80:45-72

Gerighausen U, Brautigam K, Mustafa O, Peter HU (2003) Expansion of vascular plants on an Antarctic island-a consequence of climate change? In: Huiskes AHL, Gieskes WWC, Rozema J, Schorno RML, van der Vies SM, Wolff WJ (eds) Antarctic biology in a global context. Backhuys, Leiden, pp 79-83

Gremmen NJM, Smith VR (1999) New records of alien vascular plants from Marion and Prince Edward Islands, sub-Antarctic. Polar Biol 21:401-409

Gremmen NJM, Chown SL, Marshall DJ (1998) Impact of the introduced grass Agrostis stolonifera on vegetation and soil fauna communities at Marion Island, sub-Antarctic. Biol Conserv 85:223-231

Huff DR (2003) Annual bluegrass (Роа аппиа L.). In: Casler MD, Duncan RR (eds) Turfgrass biology, genetics, and breeding. Wiley, Hoboken, pp 39-51

Hughes KA, Convey P (2010) The protection of Antarctic terrestrial ecosystems from inter- and intracontinental transfer of non-indigenous species by human activities: a review of current systems and practices. Glob Environ Change 20:96-112

Hughes KA, Worland MR (2010) Spatial distribution, habitat preference and colonisation status of two alien terrestrial invertebrate species in Antarctica. Antarct Sci 22:221-231

Hughes KA, Ott S, Bölter M, Convey P (2006) Colonisation processes. In: Bergstrom DM, Convey P, Huiskes AHL (eds) Trends in Antarctic terrestrial and limnetic ecosystems: Antarctica as a global indicator. Springer, Dordrecht, pp 35-54

Hughes KA, Convey P, Maslen NR, Smith RIL (2010a) Accidental transfer of non-native soil organisms into Antarctica on construction vehicles. Biol Invasions 2:875-891

Hughes KA, Lee JE, Ware C, Kiefer K, Bergstrom DM (2010b) Impact of anthropogenic transportation to Antarctica on alien seed viability. Polar Biol 8:1125-1130

Hughes KA, Lee JE, Tsujimoto M, Imura S, Bergstrom DM, Ware C, Lebouvier M, Huiskes AHL, Gremmen NJM, Frenot Y, Bridge PD, Chown SL (2011) Food for thought: risks of non-native species transfer to the Antarctic region with fresh produce. Biol Conserv 144:2821-2831

Kejna M (2008) Topoclimatic conditions in the vicinity of the Arctowski Station (King George Island, Antarctica) during the summer season of 2006/2007. Pol Polar Res 29:95-116

King JC, Turner J, Marshall GJ, Conolley WM, Lachlan-Cope TA (2003) Antarctic Peninsula climate variability and its causes as revealed by analysis of instrumental records. Antarct Res Ser 79:17-30

Klan Z (1947) Srovnávaci anatomie plodu rostlin okoličnatých oblasti Republiky Československé (anatomický klič). ČAVU, Praha

Korczak-Abshire M, Angiel PJ, Wierzbicki G (2011) Records of white-rumped sandpiper (Calidris fuscicollis) on the South Shetland Islands. Polar Rec 47:262-267

Kowal T (1953) Klucz do oznaczania nasion rodzaju Chenopodium L. i Atriplex L. Monogr Bot 1:87-163 
Kowal T, Rudnicka-Sternowa W (1969) Morfologia i anatomia ziarniaków krajowych gatunków rodzaju Bromus L. Monogr Bot 29:1-68

Lee JE, Chown SL (2009a) Breaching the dispersal barrier to invasion: quantification and management. Ecol Soc Am 19:1944-1959

Lee JE, Chown SL (2009b) Quantifying the propagule load associated with the construction of an Antarctic research station. Antarct Sci 21:471-475

McGraw JB, Day TA (1997) Size and characteristics of a natural seed bank in Antarctica. Arct Antarct Alp Res 29:213-216

Molina-Montenegro MA, Carrasco-Urra F, Rodrigo C, Convey P, Valladares F, Gianoli E (2012) Occurrence of the non-native annual bluegrass on the Antarctic mainland and its negative effects on native plants. Conserv Biol 26:717-723

Ochyra R, Smith RIL, Bednarek-Ochyra H (2008) The illustrated moss flora of Antarctica. Cambridge University Press, Cambridge

Olech M (1996) Human impact on terrestrial ecosystems in west Antarctica. Proc NIPR Symp Polar Biol 9:299-306

Olech M (1998) Synanthropization of the Flora of Antarctica: an issue. (In:) JB Faliński, W Adamowski, B Jackowiak (eds.) Synanthropization of plant cover in new Polish research. Phytocoenosis 10 (N.S.). Suppl Cartogr Geobot 9:269-273

Olech M (2004) Lichens of King George Island Antarctica. The Institute of Botany of the Jagiellonian University, Cracow

Olech M, Chwedorzewska KJ (2011) The first appearance and establishment of an alien vascular plant in natural habitats on the forefield of a retreating glacier in Antarctica. Antarct Sci 23:153-154

Rakusa-Suszczewski S, Krzyszowska A (1991) Assesment of the environmental impact of the "H. Arctowski" Polish Antarctic Station (Admiralty Bay, King George Island, South Shetland Islands). Pol Polar Res 12:105-121

Rudnicka-Sternowa W (1972) Studia systematyczne nad morfologią i anatomią krajowych gatunków rodzaju wiechlina Poa L. Monogr Bot 37:51-136

Rymkiewicz A (1979) Badania nad gatunkami z rodzaju Plantago L. z uwzględnieniem karpologii i chemotaksonomii. Monogr Bot 57:71-103

Sajak J (1958) Klič k určeni plodů našich Cyperaci (excl. Carex). Preslia 30:43-58

Schweingruber FH (1990) Anatòmie europäischer Hölzer. Ein Atlas zur Bestimmung europäischer Baum-, Strauch, und Zwergstrauchhölzer. Verlag Paul Haupt, Bern

Smith RIL (1996) Introduced plants in Antarctica: potential impacts and conservation issues. Biol Conserv 76:135-146

Swarbrick JT, Raymond JC (1970a) The identification of the seeds of the British Papaveraceae. Ann Bot 34:1115-1122

Swarbrick JT, Raymond JC (1970b) The identification of the seeds and achenes of the British Plantaginaceae. Ann Bot 34:1123-1129

Terauds A, Chown SL, Morgan F, Peat HJ, Watts DJ, Keys H, Convey P, Bergstrom DM (2012) Conservation biogeography of the Antarctic. Divers Distrib 18:726-741

Tutin TG (1952) Origin of Poa annua L. Nature 1969:160

Usher MB, Edwards M (1985) A dipteran from south of the Antarctic Circle: Belgica antarctica (Chironomidae) with a description of its larva. Biol J Linn Soc 23:83-93

Vernon P, Vannier G, Trehen P (1998) A comparative approach to the entomological diversity of polar regions. Acta Oecol 19:303-308

Wojciechowska B (1966) Morfologia i anatomia owoców i nasion z rodziny Labiatae ze szczególnym uwzględnieniem gatunków leczniczych. Monogr Bot 21:1-142

Wojciechowska B (1972) Studia systematyczne nad nasionami rodz. Solanaceae Pers. Monogr Bot 29:113-126 